\title{
Six days in July: Charles Lyell in the Eifel in 1831 (possibly looking at loess)
}

\author{
Ian Smalley
}

Giotto Loess Research Group; Geography Department, Leicester University, Leicester LE1 7RH, UK, e-mail: ijs4@le.ac.uk

\begin{abstract}
Charles Lyell made a geological excursion to the Eifel region in Germany in July 1831. He went to examine volcanic rocks and volcanic landscapes. He discussed this outing with Mary Somerville and Samuel \& Charlotte Hibbert. It is possible that he observed loess in the Eifel. It is hoped that his Eifel notebook is with the Lyell papers at Kinnordy and that it may be transcribed and published. Lyell spread the word on loess; Von Leonard invented it and Horner enthused about it but Lyell disseminated the essential idea of loess. There is (so far) no clear evidence that Lyell saw and appreciated loess in the Eifel region in 1831. This suggests that his first real encounter with the loess (ground or concept) was in the discussions with the Hibberts in September 1831. He certainly had substantial (reported) encounters in 1832, and was definitely interested by the time of the publication of the Principles of Geology vol. 3 in 1833.
\end{abstract}

Keywords: Charles Lyell, 1831 geological excursion to Eifel region, volcanic landscapes, loess occurrences, Leonard Horner, Samuel Hibbert

"The infinite varieties of motion in the heavens, and on the earth. obey a few laws, so universal in their application, that they regulate the curve traced by an atom which seems to be the sport of the winds, with as much certainty as the orbits of the planets."

Mary Somerville 1831

\section{Introduction}

In the preface to the third volume of his 'Principles of Geology' vol. 3 (1833) (PoG3) Charles Lyell wrote: "In the summer of 1831 I made a geological excursion to the volcanic district of the Eifel, and on my return I determined to extend my work to three volumes, the second of which appeared in January 1832. The last volume has been delayed till now [April 1833] by many interruptions, among which I may mention a tour, in the summer of 1832, up the valley of the Rhine, when I examined the loess (vol.iii, p.151)..."
That 1831 geological excursion is the subject of this paper; and the main question to be asked is did Lyell knowingly encounter the loess in the Eifel, and if he did what impression did it make on him? An important event in the history of loess scholarship is about to occur because it is the mention of loess in vol. 3 of PoG which introduces this material to the wider world. By the time he wrote the preface to PoG3, loess was obviously important to him. Possibly seeing loess in the Eifel made him realise that there was more material to put into PoG than he had initially estimated, and that a third volume 
would be needed; but that is pure speculation- there is no overt evidence that he was significantly aware of loess in July 1831.

He had several obvious reasons for being in the Eifel region in 1831. He would visit the Horner family at their house in Godesberg, and he would become engaged to marry Mary Horner, the oldest of the six Horner daughters. Leonard Horner had severed his connection with London University in 1831 and the family had moved to Godesberg/Bonn to rest and recover from that bruising encounter. The middle two daughters, Susan 15, and Katherine 14, stayed with Leonard in London and helped to tidy up his affairs. These two were both competent individuals and Katherine went on to edit the memoirs for Lyell and Horner and Charles Bunbury the botanist. (Lyell, 1881, 1890; Bunbury \& Lyell, 1891).

The geological reason for visiting the Eifel was to examine the volcanic phenomena of the region. In 1831 the activity of volcanoes, and the vision they offered of the nature of the planet, were topics of contemporary discussion, and the Eifel was the most convenient volcanic region to visit from Britain. Lyell's interest in geology had been provoked by volcanic studies and it was his review of Poulet Scrope's book on the geology of Central France (Scrope, 1827) in the Quarterly Review which was the first statement of his geological opinions and inclinations.

He did not meet Horner during this 1831 visit; Horner was still winding up his affairs in London and did not arrive at Godesberg until August. There was no Lyell/Horner interaction, no discussion of matters geological.

\section{The Eifel region}

Fig. 1 is a reproduction of fig. 48 from PoG3. This is a neat and simple sketch of the Eifel region, to the west of the Rhine and north of the Moselle. The map was produced by Leonard Horner, and reproduced in the volcanic section of PoG3.

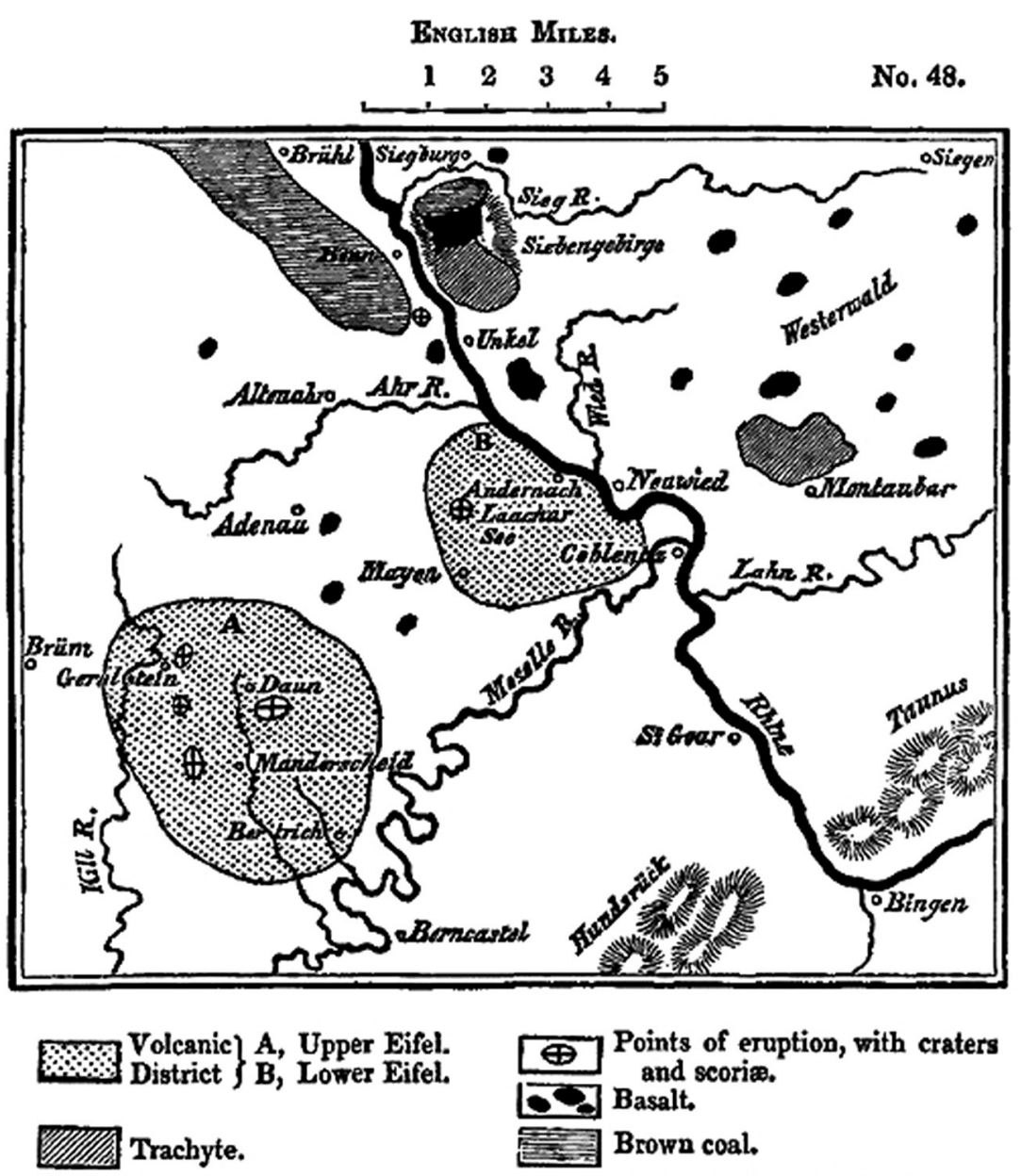

N.B. The country in that part of the map which is left blank is almost entirely composed of graywacke.
Fig. 1. Sketch map of the Eifel region by Leonard Horner. This formed fig. 48 in PoG3. 
In a letter to John Fleming, fairly soon after his return, Lyell discussed going to the Eifel: "I was very glad to hear from you, on my return from a tour of four to five weeks $[a g o]$ to the Eifel, that tract between the Rhine and Moselle, in which abundance of extinct volcanos have burst through a country which is composed of strata much like the Sidlaw (where it is free from trap), the same sandstone and shale, and similar fucoidal plants, connected in some few parts with trilobite limestone, and with genuine old coal... Through these the supra-marine volcanos burst, and strange holes have thus blown through the mountains, each eruption having been almost invariably at some new point. I daresay you may have heard of a certain case of diluvium of the Rotherberg [the Roderberg], i.e. gravel on one side of the crater of one of these modern (tertiary) volcanos." (Lyell to John Fleming 29 August 1831; Lyell, 1881, p. 328).

By omitting the word 'ago' from his hastily written text Lyell caused some confusion for later readers who thought that the tour had lasted for six weeks when in fact it was only six days. Katherine Lyell carried this misinterpretation into her 1881 memoir.

The Eifel trip was described by Wilson (1972, p. 317) in his essential Lyell biography. He sketched out the nature of the Eifel topography, and he emphasized the nature of these early vulcanological studies: "Lyell's purpose in visiting the Eiffel district was to see yet another district of extinct volcanoes, one which Leopold von Buch had used to develop his theory of the origin of dolomite by volcanic action...

A striking feature was a number of conical hills with craters at their tops. These craters usually contained lovely little lakes, nearly circular in form. However, Lyell found that although the hills bore the conical shape and the crater of a volcano, the walls of the crater were made up not of lava and scoriae, but of sedimentary strata of sandstone and shale. Yet, on one side of the lake of Gemunden Maar he found a considerable quantity of volcanic

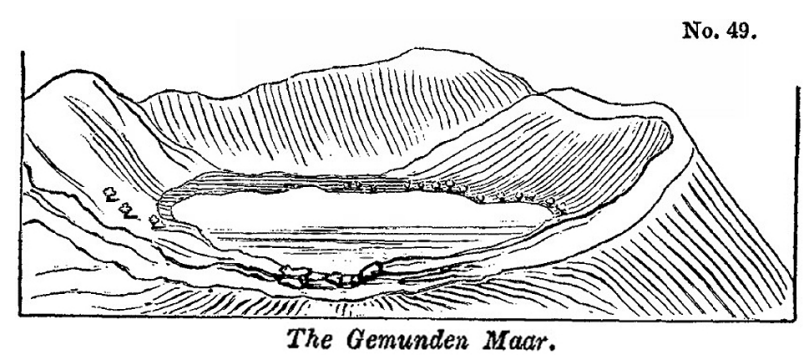

Fig. 2. Gemunder Maar; a volcano in the Eifel. This is fig. 49 from PoG3. rock and some scoriae and saw the whole surface of the soil sparkling with volcanic sand." (Wilson, 1972, p. 317).

Lyell was impressed by Gemunden Maar and included a sketch of it in PoG3 as fig. 49 (see Fig. 2). These Eifel volcanoes are of a type known as maar-diatreme volcanoes, and the Eifel is a classic region for the study of such phenomena (see Lutz \& Lorenz, 2013 for some history).

\section{After the excursion}

Lyell returned to London from Godesberg in early August 1831. He was quickly into his main taskworking on the PoG but he was certainly thinking about his voyage to the Eifel, and taking opportunities to discuss it: "Aug.14: I shall go to Chelsea, and hope to find the Somervilles. Arrived was lucky to find Mrs Somerville (Fig. 3) in the garden, told of my expedition to Eifel etc. She showed me her volume [Mechanism of the Heavens, Somerville 1831], all done save the index. The preliminary discourse will be popular, dedicated to Lord Brougham [Lord Chancellor of Great Britain], as he suggested it; no word of flattery to him." (Lyell, 1881, p. 322).

Mary Somerville was certainly one of the leading scientific intellectuals of the day. She was someone he could talk to about geology and astronomy. When her great book was published Lyell carried the complimentary copy to Germany for von Oeynhausen, who had helped him with his studies in the Eifel.

In September he was in Edinburgh; he set out to call on the Hibberts; this was to be a meeting of

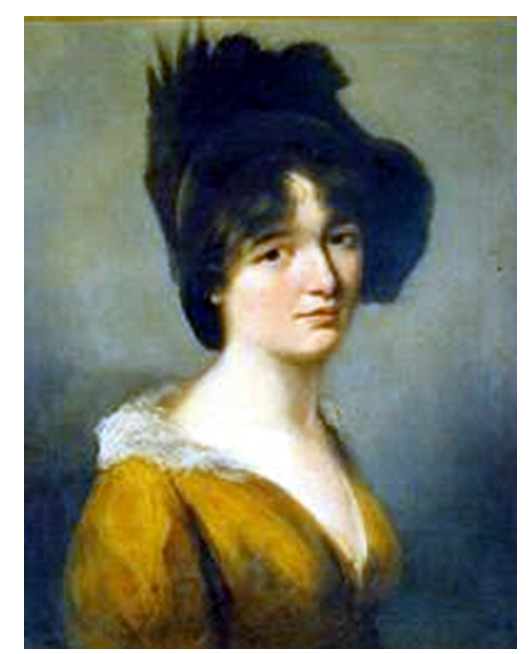

Fig. 3. Mary Somerville. A portrait of Mary Somerville as a Young Woman by John Jackson (1778-1831). The portrait hangs in Somerville College, Oxford. 


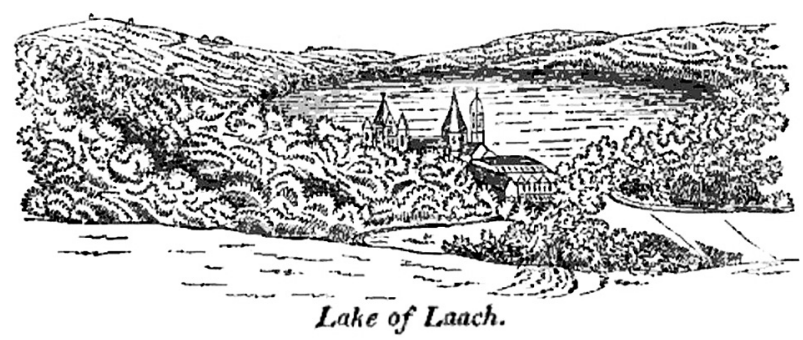

Fig. 4. Laacher See by Charlotte Hibbert. This is from the title page of Hibbert (1832). One of the diagrams much admired by Lyell.

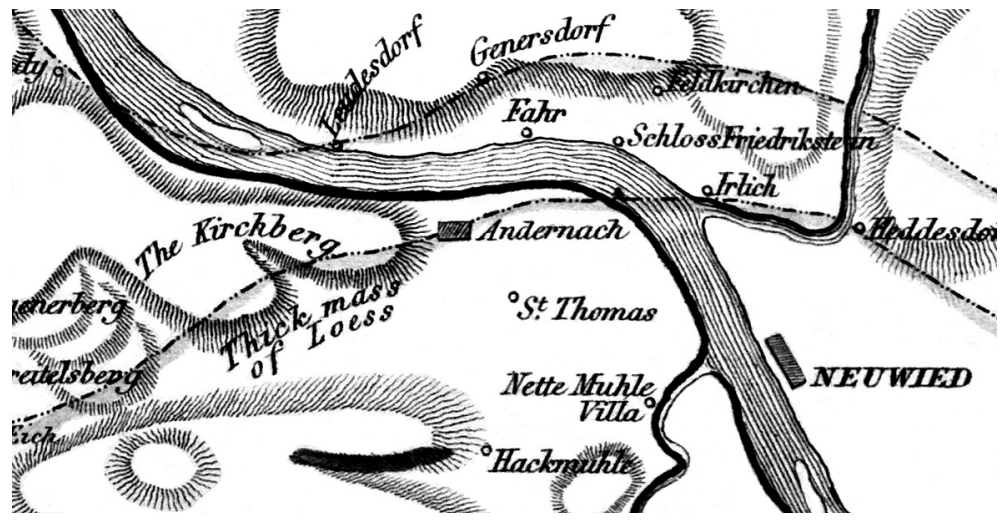

Fig. 5. Portion of the map from Hibbert (1832), showing a loess region. The map is published by the Romantic Circles website https:/ / www.rc.umd.edu. some significance in the study of the history of loess research:

"5 Sept. 1831. After this set-to I found, thanks to the lawyers' early hours here, that it was only twelve o' clock. Called on T. Allen, not in town, then at Jamieson's. I then went to Hibbert's, at home, glad of it, as I wanted a good confab about the Eifel, to which he had laid a six months siege, whereas I had only attempted to take it by storm in as many days." (Lyell, 1881, p. 332)

Lyell moved on to the family home at Kinnordy and continued with the journal which he was writing for Mary Horner: "Kinnordy: Sept.8: On my arrival here, I found everyone quite well, and two letters from you. Mrs Hibbert's drawings of the Eifel are really splendid, most of them worth publishing, yet when she began the tour, she had hardly attempted to sketch from nature. She has caught that style of [Poulet] Scrope which gives you a sort of map-picture of a country, a half panorama taken from high points." (see Fig. 4). "Never having heard of that beautiful map which Von Oeynhausen lent me, they lost much time in constructing a map, which Hibbert did trigonometrically. They have really collected both rocks and shells, and worked and sketched to great effect. In the 'loess' descending from Kruft to Andernach, they found a vast number of land shells, which seem to indicate a modern date to that formation."

The 'loess' from Kruft to Andernach'- the first loess to be discussed in English. Why does Lyell give the word the inverted comma treatment? Is he a bit uneasy about this new word? Is this perhaps the first time he has used it?

Hibbert (1832) will discuss loess in his book on the volcanoes of the Neuwied basin, but in a rather detached manner. Hibbert produced a very detailed book but one which is difficult to use because of lack of organisation and an attempt to include too much material. Loess is mentioned in three places (pp. 100,185, 197) and it is likely that this is the first discussion of loess to be published in English. The loess sections owe much to the pioneering studies of Von Leonhard, to whom the book is dedicated.

The book was accompanied by a substantial map which was entitled 'Geological map of the volcanic district bounded by the rivers Nette and Bruhl, on the Lower Rhine', largely drawn by Charlotte Hibbert. Loess occurrences are clearly marked on this map (see Fig. 5) particularly near Andernach. The map covers the region which includes the volcanic district of the Lower Eifel (see Fig. 1). The Hibbert map covers a region to the north and west of Coblenz; north of Mayen and Boos, south of Bruhl, east of Kelberg. The Laacher See is towards the centre of the sheet.

\section{1832 and 1833}

In 1831 Lyell possibly encounters loess in the Eifel. He certainly talks about it in September with the Hibberts. 
Fig. 6. The Roderberg. The farmer in the crater drilled down through $20 \mathrm{~m}$ of loess while making a well.

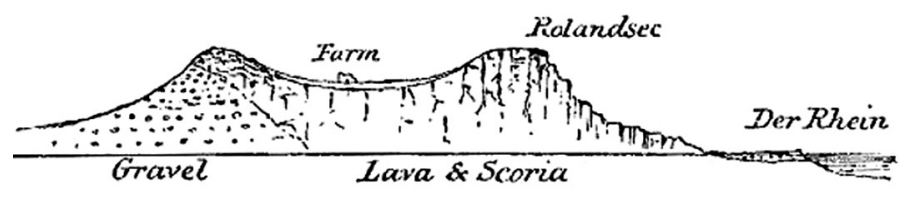

He returned to Bonn in 1832 to get married to Mary Horner. Leonard Horner had, by this time, been in Bonn for nine months, exploring and geologizing; so another question appears: had Horner encountered the loess and recognized it as an interesting geological material? Did Horner talk to Lyell about loess at the time of the wedding?

Questions for Heidelberg; how much did Lyell know about loess before the encounters with Von Leonhard and H.G. Bronn? Was their demonstration of the loess the first time that he had knowingly seen the material?

In 1832 Lyell definitely encounters loess. The field trip which he referred to at the beginning of PoG 3 was in fact his honeymoon voyage down the Rhine Valley during which he contrived to meet H.G. Bronn and K. von Leonhard (and many other geologists).

In 1833 Lyell is in the crater of the Roderberg with Horner and they are looking at loess (Fig. 6). Loess is significant in 1833.

\section{Discussion: the 1831 Notebook}

The 1831 notebook is possibly still in the Lyell collection at Kinnordy.

A thorough examination of this notebook would indicate if Lyell observed the loess in the Eifel re-

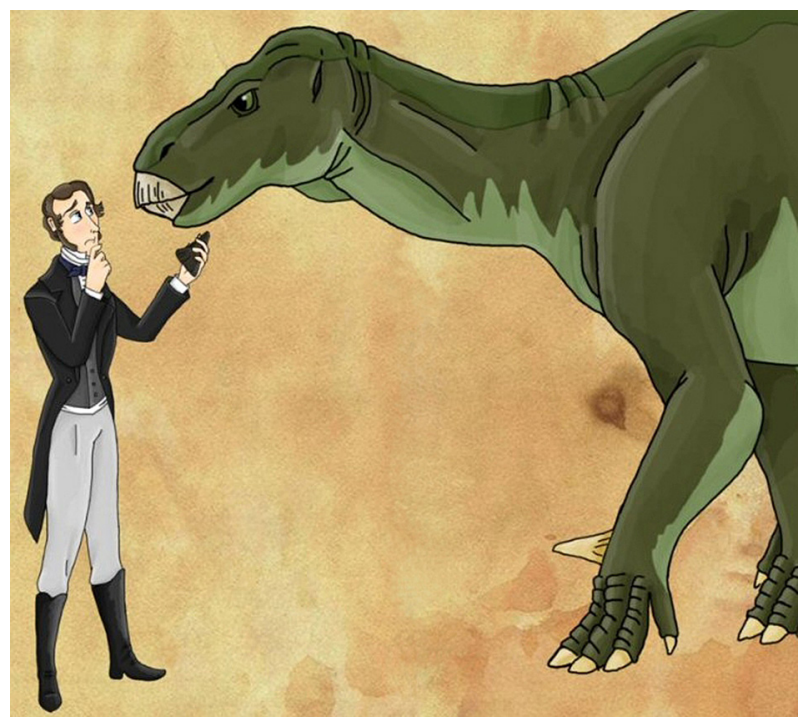

Fig. 7. Gideon Mantell; friend and correspondent of Lyell. A pioneer in the study of dinosaurs. gion. The 'loess' in the reporting for Mary in 1832 could be very significant (or simply misleading). The 'loess' presentation suggests a certain tentativeness; Lyell is approaching a new topic in a careful manner. Hibbert has no problem with the term loess and uses it freely in his book. He was, of course, well acquainted with the writings of von Leonhard and in touch with the first description and definition of loess. And he made one of the first maps, which Lyell admired. The word loess was certainly used in the Hibbert conversations of 1831; does it appear in the 1831 notebook?

On 2 August 1831 Lyell left Godesberg and returned to London. He proposed to Mary on the $12^{\text {th }}$. Wilson (1972, p. 315) clearly states that Lyell visited the Horners at Godesberg before the geological tour; so he is at Godesberg say 5-20 July, and then departs for geologizing in the Eifel, returning at the end of the month.

\section{Digression: Writing to Mantell and Scrope}

In a letter to Gideon Mantell (Lyell, 1881, p. 317) Lyell discussed his geological concerns before the trip to the Eifel. Mantell (Fig. 7) was one of Lyell's closest geological friends. Before his departure for the 1831 tour one might have expected some discussion with his closest geological friends about the nature and aims of the expedition. In the literature available there is no sign of any forethought about the Eifel voyage. The two friends closest to Lyell, in geological terms, were Mantell and Scrope. There are letters to these two correspondents in the weeks before departure (see Lyell, 1881, pp. 296-319) and they deal with interesting geological topics including experiments with granular materials as models for sediments and the subsidence of the Mediterranean basin; not the slightest hint of an awareness of loess or an interest in a possible loess landscape. The record is obviously incomplete but the Lyell (1881) record does provide considerable detail and she has chosen the letters judiciously. Lyell and Scrope and Mantell are concerned with fundamental questions of planetary science; but they were aware that close observation of small details could reveal great truths. 


\section{Conclusions}

There are no conclusions. There are possibilities, even probabilities, speculations and imaginings but the main target cannot (yet) be hit. Lyell's peregrinations and writings allow the Hibberts to be identified as important loess pioneers, and the 'Volcanos' book (Hibbert, 1832) to be seen as a ground-breaking loess volume. The 1832 story is clear, and 1833 brings PoG3 and the widespread announcement of the existence of loess. PoG was a remarkable success, there were five editions before 1837; each edition was several thousand items. In $19^{\text {th }}$ Century terms it was a world-wide success. Emphasis: world-wide- the story of loess was launched.

\section{References}

Bunbury, F.H. \& Lyell, K.M., 1891. Memorials of Sir C.J.F. Bunbury, 9 volumes. Mildenhall, reprinted by Cambridge University Press.

Hibbert, S., 1832. History of the extinct volcanos of the basin of Neuwied, on the Lower Rhine. W \& D Laing, Ed- inburgh, 262 pp. (section on loess in Loess Letter 67, www.loessletter.msu.edu)

Lutz, H. \& Lorenz, V., 2013. Early volcanological research in the Vulkaneifel, Germany, the classic region of maar-diatreme volcanoes. Bulletin Volcanologique 75, 720-743.

Lyell, C., 1833. Principles of Geology v.3. John Murray, London, 297 pp. (reprint Chicago University Press).

Lyell, K.M., 1881. Life, Letters and Journals of Sir Charles Lyell v.1. John Murray, London, 475 pp. (reprinted Elibron Classics 2007).

Lyell, K.M., 1890. Memoir of Leonard Horner FRS FGS v.1. Womens Printing Society Ltd, London, 376 pp. (reprinted Cambridge University Press 2011).

Scrope, G.P., 1827. Memoir on the Geology of Central France: including the volcanic formations of Auvergne, the Velay, and the Vivarais. Longman, Rees, Orme, Brown \& Green, London, $182 \mathrm{pp}$.

Somerville, M., 1831. Mechanism of the Heavens. John Murray, London, 621 pp. (reprinted Forgotten Books 2012).

Wilson, L.G., 1972. Charles Lyell, The Years to 1841: the Revolution in Geology. Yale University Press, New Haven, 553 pp.

Manuscript received: 7 March 2017

Revision accepted: 5 May 2017 